\title{
Pandemi Sürecinde Ev: Gündelik Pratikler ve Yeni Kamusallığın Deneyimi
}

*

\author{
Zemzem Taşgüzen Pülat ${ }^{1}$ \\ ORCID: 0000-0001-7766-4487
}

\section{Öz}

Ev, içinde konumlandı̆̆ımız hallerimizle birlikte sürekli değiştirdiğimiz; en fazla değiş̧imin kendisini konuşmamız gereken bir kamusallı̆̆a işaret eder. Bu değiş̧im, zamanı da vurgulamayı gerektirir; gündelik zaman, toplumsal süreçler, kırılma anları vb. Bir kırılma, aynı zamanda "ortaklaşma" durumlarından biri, dünyada milyonlarca insanı "evde kalmaya" zorlayan Covid-19 pandemisi olmuştur. Pratiklerimizin değiştiğgi ve yenilerinin eve girdiği bu süreçte, ortak bir sorunsalın içinden geçen bireyler olarak evi nasıl dönüştürdük ve yeni kamusallı̆̆ı nasıl deneyimledik? Farkl deneyimleri ortaya koymak, genelleştirme eğiliminin baskın olduğu her

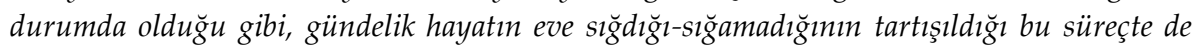
önemlidir. Gündelik değişimi anlayabilmek açısından, çalışma ortamını eve taşıyabilen, Türkiye 'de farklı şehirlerde yaşayan yedi kadınla çevrimiç̧i/görüntülü görüşmeler gerçekleştirildi. Görüşmeler sonucunda bazı meselelerin ön plana çıktı̆̆ı, farklı şekillerde tekrarlandığı görülmüştür: pratiklerin ve mekânın dönüşümü, mekândan farklı istifade etme yollarının aranması, boş zamana yabancılaşma, kişinin gündelik ritmiyle, toplumsal ritmin uzlaşamama hali ve kamusal alan eksikliğinin deneyimlenme halleri. Bu çalışmada pandemi durumuyla çatışmaluzlaşma kaygısı taşımadan, meseleye gündelik pratiklerin ve yeni kamusallığın deneyimi açısından eleştirel yaklaşmak amaçlanmıştır. Bu kapsamda, görüşme yapılan öznelerin gündelik hayat anlatıları Henri Lefebvre 'nin boş zaman, yabancılaşma, ritim kavramları üzerinden tartışılmıştır.

Anahtar Kelimeler: ev, covid-19, gündelik pratikler, deneyim, kamusal alan

\footnotetext{
${ }^{1}$ Dr. Öğretim Üyesi, Mardin Artuklu Üniversitesi, E-mail: zemzemtasguzen@artuklu.edu.tr idealkent @ Kent Araştırmaları Dergisi (Journal of Urban Studies) 


\title{
Home In Times Of The Pandemic: Daily Practices and The Experiences Of New Publicity
}

\author{
Zemzem Taşgüzen Pülat² \\ ORCID: 0000-0001-7766-4487
}

\begin{abstract}
The home constantly changes according to the states we are in; it refers to a domain of action and publicity that we need to discuss the change itself. This also requires an emphasis on temporality; of everyday, social process and also of breaking points. One of these breaking points is the Covid19 pandemic that forces millions of people to "stay home" around the world. In this period where our domestic practices change, and re-defined with the introduction of new practices, how do we transform the house as individuals and how we are affected by the new publicity? In order to understand this change, seven women from Turkey who were able to work from home were interviewed by Zoom platform. As a result of the interviews, it was seen that some issues were repeated in different ways: the transformation of practices and space, failure to reconcile with the daily rhythm of the person and social rhythm and experiencing the lack of public space. The research approaches the issue critically in terms of housing studies and notion of everyday. In this context, the everyday narratives of individuals will be discussed through Henri Lefebvre's concepts of free time, alienation and rhythm.
\end{abstract}

Keywords: home, covid-19, daily practices, experience, public space

\footnotetext{
2 Asst. Prof., Mardin Artuklu University, E-mail: zemzemtasguzen@artuklu.edu.tr idealkent @ Kent Araştırmaları Dergisi (Journal of Urban Studies) http://idealkentdergisi.com 


\section{Giriş: Korona Günlerinde Ev ${ }^{3}$}

Ev, çeşitli ikilikler çerçevesinde tanımlanan, zıtlıkların içinden kurulan bir alan olageldi çoğu zaman. İçerisi-dışarısı, tekin-tekinsizlik, bireysel-toplumsal, özelkamusal eve dair farklı yazınsal alanlarda karşımıza çıkabilecek kavram ikiliklerini oluştururlar. Evden kaçmaya dair oldukça geniş bir yazınsal külliyat, kapı eşiğinden dışarı adım atmayı özgürlükle ilişkilendirir. "Gitmek ya da kalmak" diyor N. Gürbilek (2010, s.75), "evin bize dayattığı -yoksa bağışladığı mı demeliyim- bir ikilem bu". Ev, bu kavram ikiliklerinin bir tarafında konumlanup diğer tarafı dışlamaz; aksine bu kavram ikiliklerinin gri alanlarında, çeperlerinde oluşur. İçerideyken dışarıya dair meseleler, durumlar, şeyler içeriye sızar. Ev, bireysel ve toplumsal var oluşumuzu kurduğumuz yer, toplumsallık demektir. Bireyi toplumsaldan ayıran çizgi nasıl kolayca tayin edilemezse, ev de bireysel ve toplumsal ara kesitleri imler, sürekli yeniden oluşturur. Ev, Freud'un "tekinsiz" kavramıla ilgili söylediklerini çağrıştırır; yabancı ve bilinmedik olanla değil, aşina ve çok iyi bilinen, ancak bastırılma sonucu yabancılaşılmış olan bir şeyle karşılaşmanın potansiyel gerilimleriyle bizi yüzleştirir (aktaran Suner, 2015, s. 175).

Diğer yandan ev, günümüzde en çok da "tekin, güvenli yer" kavramıyla ilişkilendirilmektedir. "Kant modernitenin şafağında evden sokağa çıkmanın keyfi ve neşesiyle yazıyordu, bugün biz modernitenin alacakaranlığında ensemizde 'sıçan deliği'nin soğuk nefesiyle, keder ve korkuyla sığınabileceğimiz evler arıyoruz ya da her an aramak zorunda kalabiliriz" (Argın'dan aktaran Gürbilek, 2020, s. 25).

Pandemi durumunun ortaya çıkmasıyla birlikte eve dair, belki de şu ana kadar hiç olmadığı şekilde büyük bir kalabalıkla birlikte düşünmeye başlarız. Evin sloganlaşmasına şahitlik edip ("evdekal hayat kurtar", "evde yaşam var", "hayat eve sığar"), ev imgeleri bombardımanına maruz kalırız. Her yönden evin, dışarıda gerçekleştirilen birçok eylemi içerebileceğine dair mesajlarla karşılaşırız. Ev, yeniden bir ikiliğin öznesi olagelir. Tekinsiz dışarıya karşı "güvende" olabileceğimiz "tek yer"dir artık. Geçmişte kimi zaman yüceltilerek "dokunulmaz" hale getirilen, mimarlık üretimi alanında ve yazınsal anlamda

\footnotetext{
${ }^{3}$ Gabriel Garcia Marquez'in "Kolera Günlerinde Aşk" romanına referansla atılmış bir başlık. Dünyanın salgınlarla imtihanının tarihsel bağlamının da araştırıldığı korona günlerinde; geçmiş salgınlara bakarak oradaki deneyimi ve süreci anlama çabası, sırf başlığının uyandırdığı etkiyle dahi olsa kitabı, sosyal mecralarda, günümüz pandemi sürecinin en çok okunan ve paylaşılan kitaplarından biri yaptı.
} 
"gerektiği ölçüde" ve tüm dinamikleriyle ele alınmaktan kaçınılan, pek de dikkate alınmayan evin bir kez daha "yüceltildiğine" şahitlik ediyoruz. ${ }^{4} \mathrm{Bu}$ durumda Gürbilek (2020, s. 11)'in şu cümlesini hatıllamadan edemeyiz: "Yığınların yersiz yurtsuzluğa zorlandığı bir çağda evin mecazi anlamının düzanlamını silecek kadar öne çıkmasında bir terslik var".

Kimi yaklaşıma göre evin bu "yeni" hali bir tür kuşatılma süreci. Çeşitli kurumların beklenti ve eylemleriyle, tüketim ritüelleriyle, hizmet alımlarıyla, pratiklerin dönüşümüyle ev hiç olmadığı kadar sınırlandırılmış, denetim altına alınmış ve kapatılmış durumda. ${ }^{5}$ Bir başka yaklaşıma göre ise; toplumsal üretimin mekânı olan "ev"den yeni toplumsal imkânlar üretilecektir. ${ }^{6}$ Herhangi bir teze tutunmadan, evin yüceltilmesine de mesafelenerek, özneler nezdinde durumuna bakmak ve eleştirel yaklaşmak 'yeni ezberler 'yapmaktan bizi kurtarabilir. Böylece birey ve gündelik hayat arasındaki diyalojik süreç, tanımlanmış söylemlerin ötesine geçmeye olanak sağlayabilir.

\section{Gerekçe ve Yöntem}

Bir diyalog oluşturabilmek, süreçteki tikel farklılıkları ve deneyim çeşitliliğini anlayabilmek açısından bu çalışmada, bireysel derinlikli görüşme yöntemi kullanılmıştır. Evsel pratiklerin ve değişiminin daha net anlaşılması açısından evde 'birileriyle' birlikte yaşayan kişiler seçilmiştir. Görüşmeler 8 Mayıs27 Mayıs 2020 tarihleri arasında gerçekleştirilmiş; görüşmeciler, yazarın kendi çevresinden seçilmiştir. Görüşmecilerin üçü Mardin'de, biri İstanbul'da, ikisi Ankara'da ve biri Urfa'da yaşamaktadır.7 Görüşmecilerle, yapılandırılmamış görüşmeler gerçekleştirilmiş olup; çalışmanın amacı kişilere görüşme öncesi açıklanmıştır. Verilerinin kaybolmaması adına görüşmeler

\footnotetext{
${ }^{4}$ Burada bahsedilen durum, evin / konutun çoğunlukla fiziksel, tipolojik, morfolojik bir yaklaşımla ele alınması; gündelik ve domestik yaşamın geri planda kalmasıdır. Yazarın doktora tez çalışması bu konuda bir eleştiri sunmaktadır: Domestik Yaşam: Bir Konut Kuramı İçin Altlık, Mardin Artuklu Üniversitesi Fen Bilimleri Enstitüsü,(Basılmamış Doktora Tezi), 2019.

${ }^{5}$ Bu yazılardan birini Hakkı Yırtıcı kaleme aldı: “Toplama Ev: Ev İşgal Altında”, 2020.

${ }^{6} \mathrm{Bu}$ yaklaşımda, bazı durumlarda mimarlığın ve mikro ölçekte de evin "kurtarıcı" pozisyonuna sokulması riski bulunmaktadır. Mimarlığın yüceltilme yaklaşımına mesafelenerek, ama mekânın, kentsel örgütlenmenin de önemini ıskalamayan yaklaşımlar geliştirmenin önemli olduğu düşünülmektedir. Bunlardan biri, "Yeni Deneyimlerin Mahali Olarak: Salgın Günlerinde Ev" (Düzen, Gezici Yalçın, 2020) isimli makaleyle bu çalışma tamamlandığında karşılaştım. Evin özneler açısından anlamı ve deneyimlenmesi üzerine, pandemi öncesinde olduğu gibi pandemi sonrasında da, daha fazla çalışmaya ihtiyaç var.

${ }^{7} \mathrm{Bu}$ çalışmada ismi geçen, domestik deneyimlerini paylaşarak katkıda bulunan tüm görüşmecilere çok teşekkür ederim.
} 
dijital ortamda kayıt altına alınmış, bu noktada görüşmecilerin onayı alınmıştır. Görüşmeler yaklaşık 45 dakika sürmüş, görüşmecilere bilgilendirilmiş onay formu imzalatılmıştır. Çalışmanın amaçlarından biri, bu öznel verilerin pandemi dönemi açısından literatüre farklı boyutlarla katkıda bulunmasıdır. Görüşmeler standart sorularla yönlendirilmiş olmamakla birlikte genel çerçeveyi; pratiklerdeki değişim, pandemi sürecinde eve giren nesneler-eşyalar, süreçte en fazla-en az vakit geçirilen alanlar, kamusal eylemler vb. oluşturmuştur. Görüşmecilerin gündelik hayat anlatıları Henri Lefebvre'nin boş zaman, yabanclaşma ve ritim kavramları üzerinden tartışılmıştır.

\section{Amaç ve Kavramsal Çerçeve}

Görüşmeler sonucunda bazı meselelerin ön plana çıktığı, görüşmeciler tarafından farklı şekillerde tekrarlandığı görülmüştür. Bunları şu şekilde sıralamak mümkün: Pratiklerin ve mekânın dönüşümü, mekândan istifade etme yollarının aranması, boş zaman (ve pratiklere) yabancılaşma, kişinin gündelik/evsel ritmiyle, toplumsal (kamusal) ritimlerin uzlaşamama hali.

Pandemiyle birlikte bireyin zaman kavrayışı değişmiş; günün ancak belli saatlerinde evde olan birey, pandemiyle birlikte tüm gün evde bulunmaya başlamıştır. Bu durumun psikolojik ve fiziksel etkileri bir yana; gündelik pratikler, bireyin yaşadığı mekan ve kullandığı nesneler açısından önemli etkileri vardır. Çalışma dışındaki zamanı, genel olarak boş zaman olarak tariflemek mümkündür. Boş zaman kavramı, antik çağdan bu yana tartışlan çok boyutlu bir kavram olarak bu çalışmada, H. Lefebvre ve B. Chul Han yaklaşımından tartışılmıştır. Lefebvre (2010), "boş zaman”a gündelik hayat ekseninden detaylı bir açılım sağlar. Gündelik ve domestik zamanın ev mekansallığında iç içe geçmesi yeni bir ortak durumdur. Diğer yandan bu ortak durumu her birey kendince ve koşullarınca deneyimler. Lefebvre'nin ritim vurgusu, beden-mekan-olay örgüsüne dair açlımları, bu yeni deneyimi konumlandırmak açısından önemlidir. Chul Han ise (2019), Zamanın Kokusu'nda "derin düşünce zamanı", "serbest zaman" gibi ifadeler ekseninde, antik çağdan günümüze, boş zamana dair bir izlek sunar.

Bu çalışma, her iki yazarın da açılımları üzerinden, pandemi halinin yarattı̆̆ "zaman" kavrayışını tartışmayı amaçlar. Pandemi sürecinde, evden çalışabilen bireyin "boş zamanı" neye dönüşmüştür? Dışarının/mekanik zamanının devre dışı kalmasıyla birlikte bireyin kendi evsel zamanının/ritminin ön plana çıkması, bunun deneyimlenme biçimlerinin tarihsel bir izlek 
üzerinden okunması, bu yeni hali anlamlandırmayı ve tartışmayı kolaylaştırır. Böylece "Giriş" bölümünde belirtilen "evin işgal edildiğine" dair tartışmalara da bu noktada eklemlenmek amaçlanmaktadır.

Yabancılaşma kavramı, görüşmecilerin gündelik anlatılarının işaret ettiği bir diğer kavram olarak, önemlidir. Kavramın, "emek" ilişkisine vurgu yapan Marx (2018, s. 80), "insanı (1) doğadan, ve (2) kendinden, kendi etkin işlevlerinden, kendi hayat-etkinliğinden yabancılaştırırken, yabancılaşmış emek, türü insana yabanclaştırır" der. "Özgür", "bilinçli etkinlik" insanın kendine ve üretimine yabanclaşmaması açısından gereklidir. Henri Lefebvre (2012), Gündelik Hayatın Eleştirisi-II'de yabancılaşma kavramının tarihselliğine, Hegel'in ve Marx'ın yaklaşımlarına vurgu yaparak, kendi önermelerini tartışmaya açar. Yabancılaşmanın sayısız biçiminin olmasını, faaliyetlerin şeyleşmesini, çeşitli yabancılaşma biçimlerinin birbirinden farklılıklarını, gündelik hayattaki yabancılaşmayı vb. somut örnekler üzerinden açıklar (ss. 219-229). Boş zaman kavramı gibi yabanclaşma kavramının da oturduğu bu tarihsel zemine, pandemi sürecini de eklemek mümkün. Pandemi sürecinin özneler nezdinde farklı sonuçlarının olabileceği gerçeğiyle birlikte, yarattı̆̆ "yabancılaşma biçimlerine" bakmak, genel kabullerin sorgulanmasını sağlayabilir.

Yaşayanların, evlerinin 'fizikselliğini' yorumlama ve dönüştürme biçimlerini, gündelik pratiklerle birlikte tartışmak bir diğer önemli başlığı oluşturmaktadır. Son bölümde ise 'yeni' kamusallığı deşifre etmek; yeni pratiklerin deneyimlenme hallerini ve kentsel ilişkileri tartışmak amaçlanmıştır. Çalışmanın kavramsal açılımı, Şekil 1'deki kavramsal açlım diyagramında özetlenmiştir. Bu diyagramda boş zaman, gündelik pratiklerin değişimi ve kamusal ritmin evsel ritimle çatışma hali ana başlıkları altında çalışmanın tartışma güzergahı ve kavramları okunmaktadır. Son başlık olan "yeni kamusallığın deneyimi", kamusal ritmin ve evsel ritmin çatışma halinin bir çıktısı olarak bu çalışmada yorumlanmaktadır. Bu diyagramda özetlenen kavramsal ilişkiler ağının, belli bir zamansal aralıktaki (Mart-Mayıs 2020) dinamik bir süreci tariflediği vurgulanmalıdır.

\section{Eve Yabancılaşma Biçimleri}

Bazı görüşmecilerin evdeki sürece dair ifadeleri; hanehalkı ve nesnelerle ilişkiler, pratikler ve boş zaman üzerine yorumları, evi yabancılaşma kavramıyla birlikte tartışmanın önemine işaret eder (bakınız Şekil 1). Gündelik ve domestik pratiklere yabancllaşma, bireyin eve kapanma sürecinde başka bir biçime dönüşmüş, her bireyin yabancılaşması da evdeki deneyim ve kurduğu 
ilişkisellikler bağlamında farklılaşmıştır. Uyku, yemek ve çalışma, yabanclaşılan pratiklerin başında gelmektedir.

Uyku düzenim çok değişti, allak bullak oldu. Yemek yapasım, kahvaltı hazırlayasim, bir şey üretesim yok açıkçası. Başlangıçta, evde kalacă̆ımızı, okula gitmeyeceğimizi ilan ettiklerinde, evi seven biri olarak, daha fazla okuyacağımı, tezime daha iyi konsantre olacağımı, çocuğumla daha fazla ilgileneceğimi düşündü̆̈̈̈m için sevinmiştir. Ama öyle olmadr. Bunlar yapamamakla birlikte sıkıldım evden. (Bahar, kişisel iletişim, 9 Mayıs 2020).

Temel pratiklerle ilişkimizin farklılaşmasının yanında, uzaktan çalışma yöntemlerin şu ana kadar hiç olmadığı şekilde -aynı anda- etkinleştirilmesiyle birlikte ev içinde ve ekranların önünde uzun saatlere karşılık gelen 'yeni' bir pratik oluşmakta ve bu pratiğin, Lefebvre (2019)'nin “teknolojik yabanc1laşmayla" ilgili söylemlerine yeni bir 'tipoloji 'oluşturduğu düşünülmektedir:

Boş vakitler, parçalı çalışmaya kıyasla yabancılaşmadan kurtarır', fakat eğlenmenin ve oyalanmanın da kendine özgü yabancılaşmaları vardır. Falanca teknik insan faaliyetlerini doğa karşısında ya da daha az etkin bir teknik karşısında ýabancilaşmadan kurtarır', fakat daha derin olabilecek teknolojik bir yabancılaşma getirir (parçalı çalışma, tekniğin toplumsal buyrukları vb) (Lefebvre, 2019, s. 221).

Pratikler arasındaki zaman ve mekân sınırlarının muğlaklaşmasının, yabanclaşmanın ölçütünü belirlediği düşünülmektedir. Çalışma mekânı, evin salonu, yatak odası, çalışma odası ya da mutfağı olabilir. Evden çalışmanın aynı zamanda bilgisayar ekranında kişinin kendisiyle birlikte bulunduğu 'arka planın' da görünmesini gerektirdiği durumlarda, başkaları tarafından neyin/ne kadarının güründüğ̈̈/görünmediği ve mahremiyet kavramı gibi başka dinamikler de devreye girmektedir. Hanehalkının çalışma ortamında bulunması, bireysel alanın oluşması ya da oluşamaması gibi durumlar yabancılaşma ölçütlerini etkilemektedir. Evimize kendi seçimimizle başkalarını aldığımız bir durumdan, seçim yapamadığımız bir duruma geçiş 'oldukça beklenmedik' ve hızlı gerçekleşmiştir.

Büyük kaos aslinda. Dengeyi kuramıyorsun, ev temizlerken aklnn yapman gerekenlerde kalıyor, çalı̧ırken aklın evde yapılması gerekenlere gidiyor. Evde olduğum için sürekli, sabah kalktığımda evdeki kanepeleri, koltuğu, battaniyeyi dağınık görmeye tahammül edemiyorum. Çünkü o artık benim çalışma manzaram. Orayı toplamam gerektiğini düşünüyorum. Mutfakta mermerin üzerine bir şeyler varsa sabah kalktığımda orayı toplama ihtiyacı hissediyorum. İki saat çalışı, öğle yemeğini hazırlamak için tekrar mutfağa gidiyorum. Tuvalete gittiysem çamaşır yıkayayım diyorum. (Dilan, kişisel iletişim, 8 Mayıs 2020). 
Gündelik hayatın, Lefebvre'nin ifadesiyle, bir "veçhesi" olarak çalışma mekanizmaları tarihsel süreç içerisinde ve özellikle günümüz dijital örgütlenmede gündelik hayatın diğer veçhelerini baskılamakta, bir yönüyle de denetlemektedir: "Uyku, açlık ve susuzluk, boşaltım vs. ile ilgili biyolojik ritimlerimiz toplumsal çevre ve çalışma hayatımız tarafından giderek daha fazla koşullanyor. Bir dizi şekilde davranabilmek üzere kendimizi eğitiyoruz ve eğitiliyoruz" (Lefebvre, 2018, s. 15). "Boş vaktin" tanım ve içeriğinin de değiştiği bu süreçte, pratikler arasındaki mekânsal-zamansal sınırların muğlaklaşmasının da etkisiyle, toplumsal üretim ve beklentilerin "yeri" artmıştır. Lefebvre (2012), "boş vakit gündelik hayattan kopmalıdır" derken bunu, bireye yeni kaygıların yüklenmemesi, sürecin bir tür baskı aracına dönüşmemesi olarak ifade eder (s. 38).

Şey konusu beni sıktl, hala da sıkıyor. Bir sürü arkadaşımla tartıştı̆̆ım için söyleyebilirim. Sürekli üretken olma mevzusu var ya. Sürekli bir şey üretmelisin, bir şey yapmalısın. Öyle de değil aslında. Ben şeyi fark ettim evet belki daha iyi konsantre oluyorum, dışarıdaki uyaranlar yok. Tüm gün bu masa etrafindayım sonuçta. Ama daha az verimle dışarıda olmayı tercih ederim. Çünkü onun verdiği kafa rahatlı̆̆ı çok başka. (Burcu, kişisel iletişim, 27 Mayıs 2020).

Gündelik hayatın müphemliği içerisinde boş vakit, öznenin "rölaks olma" ${ }^{\prime 8}$ zamanıdır. Diğer yandan "ne yazık ki boş zaman toplumsal hayatın diğer alanlarından, özellikle de çalışmadan gelişigüzel bir biçimde ayrılamaz" (Gardiner, 2016, s. 123). Pandemi sürecinde bu ayrım iyice belirsizleşir. Gündelik eylemlerin iç içe geçme hali, verimlilik beklentileriyle birleşince öznenin, kendi eylemlerine de bir anlamda yabancılaşmasına neden olur. $\mathrm{Bu}$ sürecin bireyler nezdinde farklı deneyimlenme hallerini göz ardı ederek ve gündelik ritmin "olağan" varsayımına dayanarak özneden beklenen iş yükleri yeni baskı biçimleri oluşturur. Yalnız somut durumlar ve işler değil, özne de çeşitli söylem ve eylemleriyle başkaları üzerinde bu baskıyı yaratır. Bazen yabancılaşma, "dijitalleşmenin aşırı övülmesi" olarak ortaya çıarken, bazen de "üretkenlik" söylemlerinde belirmektedir.

Zorla bir anda dijitalleştik ya. Bunun aşır övülmesi beni rahatsız ediyor. Aslında farklı değil düşününce zoom ortamı bir öğrenciye yan yana kritik vermekten. Bunun böyle bir şey gibi, müthiş bir dijitalleşme gibi sunulması, bu kadar yüceltilmesi bana

\footnotetext{
${ }^{8}$ Lefebvre (2012)'de rölaks olma, boş vakit, bireyin kendini gerçekleştirmesi olarak önemlidir. Lefebvre (ss. 34-48), boş vakti açıklarken özellikle içeriğe de vurgu yapar. Boş vaktin, gündelik hayatı parçaladığı durumda, aktüeli reddeden, yüzeysel, ani imgesellikler ortaya çıktığından bahseder.
} 
garip geliyor. Aslında bir farkı da yok. Sadece zorunlu bir süreçten buna evrildik gibi düşünüyorum. (Burcu, kişisel iletişim, 27 Mayıs 2020).

Lefebvre (2019)'ye göre, "başka'nun bilinci olmasa her bilinç durur, dolay1syyla engellenir (öyle ki yabancılaşma teorisinde, başka'nın bilincinde-olmamak eksiksiz yabanclaşmanın ta kendisidir, yabancılaşmanın hareketsizliğidir). Sonuç olarak, "başka"yı algılamanın insan algısı açısından temel oluşturduğuna kuşku yoktur" (Lefebvre, 2019, s. 128). Bireyin kendi verimlilik ölçütü böyle bir yanılsama yaratır, "başka"nın deneyimini görmeyi engeller. Ev koşullarındaki farklılıkların, evdeki teknolojik donanımların yarattığı eşitsizliklere, evdeki hanehalkı sayısı ve ilişkilerin çeşitliliğine dair kayıtsızlık yeni toplumsal yabancılaşma biçimleri yaratmaktadır.

Hep şey diyorlardı ya. Çok fazla vaktimiz var. Şu diziyi izleyelim, şu kadar kitap bitirelim. Şuna yoğunlaşalım. Bir heyecan oluştu insanlarda ilk zamanlarda. Ama bende hiç öyle olmadl. Eskisinden daha az vaktim var. Evet, evin içindeyiz sürekli. Ama ya bunu yönetmek konusunda çok iyi değilim. Ya da gerçekten evin içindeki o rutine girdiğin zaman zamansızlaşıyorsun. Vaktin kalmıyor bir şeylere, kendine. Evin içindesin ve ne zaman uyuduğunun ne zaman uyandığının bir önemi yok. (Bahar, kişisel iletişim, 9 Mayıs 2020).

Byung-Chul Han (2019) Zamanın Kokusu kitabının "Boş Zamanın Kısa Bir Tarihi" isimli bölümünde, "modern çağda çalışmanın mutlaklaşması, hatta yüceltilmesine yol açan değer değişimi oldukça karmaşık ve çok katmanlı bir olgudur" (s. 102) derken boş zamanın nasıl ortadan kalktığını da tarifler: "Bütün eylem enerjileri emek tarafından tamamen massedildiğinden, emek d1şındaki zamanı doldurabilecek yegane şey de tekrar bütün gücüyle çalışmayı sağlayacak edilgen bir eğlence ve dinlencedir" (s. 106). Lefebvre'nin "rölaks zamanı" edilgen bir dinlenme tariflemez; başkayla karşılaşmayı, dışarının gözlenmesini, kentsel-mekânsal bir farkındalığı, aktif bir eylemi imler. Chung Hal ise, "boş zaman" yerine "serbest zaman" ifadesini tercih eder. Çalışma faaliyetlerinin parçası olmayan bir "aralık" bireyin, içini ister aktif bir şekilde doldursun ya da "nasıl isterse", önemli ve gereklidir. "Dünyayı ve kültürü oluşturan olaylar nadiren aktif eylemde bulunan bir öznenin bilinçli kararlarından kaynaklanır. Aksine serbest zamanın, zorlamadan muaf bir oyunun veya serbest imgelemin ürünleridir bunlar"(Chul Han, 2019, s. 111). Bu noktada "eyleme" mesafelenerek "durmayı" öncelemesi, sürekli eyleyen/eylemesi gereken birey algısının sorgulanmasını amaçlar. Boş zamanın öznenin isteği dışındaki "şeylerle" dolması, gündelikliğin kılcallarına kadar yapılan- 
ması ve verimliliğin standartlarının yeniden tanımlanması anlamına gelmekle birlikte, gündelik deneyimin öneminin kavranması ve kamusal/kentsel performanslara dair yeni tartışmaları tetiklemesi açısından da kritik önem taşımaktadır.

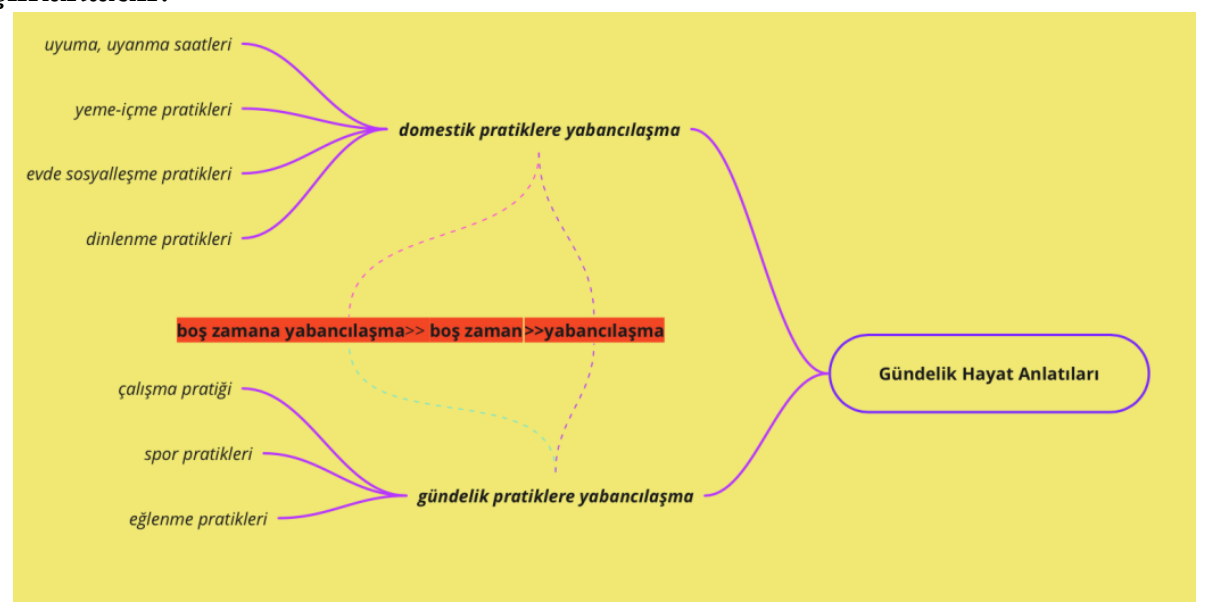

Şekil 1. Yabancılaşma kavramı açlım diyagramı

\section{Olanla İdare Etmemek: Evi Yeniden Üretmek ${ }^{9}$}

Kendiliğinden, her birimizin tercihleri, referansları, frekansları var; her birimizin ritimleri, kendi kalbimiz veya soluğumuza ve ayrıca kendi çalışma, dinlenme, uyanık ve uyku saatlerimize referansla değerlendirmek zorundayiz (Lefebvre, 2018, s. 34-35).

Pandemi sürecinin beraberinde getirdiği düzenlemeler toplumsalın, kamusal eylemlerini yapılandırırken, evdeki pratiklerin de "bir anlamda" sınırlanmasına neden olmaktadır. Bu sınırlanma bireyin evin anlamını ve fiziksel sınırlarını yeniden tanımlasına ve evini çeşitli şekillerde dönüştürmesine ise olanak sağlamaktadır. Daha önce yapmakta zorlanmadığımız, yaparken üzerinde düşünmediğimiz ve rutinimiz haline gelen birçok tavır, uygulama ve pratikler değişmektedir. Market alış-verişi, temizlik, yeme-içme, çalışma, spor, yürüme, uyuma vb. birçok pratiğin gündelik hayatımızdaki yeri, süresi

\footnotetext{
9 De Certeau (2009)'nun Gündelik Hayatın Keşfi-I kitabında "Olanla İdare Etmek: Kullanımlar ve Taktikler" isimli bir bölüm bulunmaktadır. ss. 103-120. Certeau bu bölümde bireyin, sistem ve denetimi karşısında takındığı taktiklere odaklanır. Kullanım, eylemi de içerir, bireyin sistemi "içeriden" dönüştürmeye yarayan tarzları olarak özetlenebilir. "Bunlar sistemin örgütleyici tekniklerinin çeki düzen verdiği bir mekânda öngörülemeyen tümcelerdir" (s. 110). Evdeki eylemler de bir bakıma bu tür eylemlerdir.
} 
ve uygulama biçimi farklılaşır. Eşyaların ve nesnelerin kullanım durumu da dâhil olmak üzere gündelik değişimler evin, özneler nezdinde deneyimlenme durumunu da değiştirir. Daha önce en fazla bulunulan mekânlar en az bulunulan mekânlara, daha önce pek kullanılmayan nesneler, eşyalar çeşitli şekillerde kullanılan nesnelere dönüşmüş olabilir ya da tam tersi. Kimi özneler için ise nesneler/eşyalar/mobilyalar eskisi kadar önemsenen şeyler olmaktan çıar. Nesnelerden/eşyalardan öte aile bireylerine iyi gelen eylemlerin gündelik pratikteki yeri artmış; yeni pratikler oluşmuş, bazı pratiklerin ise mekânı değişmiştir (bakınız Şekil 2 ve Şekil 3).

Eşya severim, evde değişiklik yapmayı, yenilik severim. Birçok eşya, yer gözüme batardı. Şu duvarın rengi ş̧̈yle mi olsa, balkona yeni bir mobilya mı alsam diye düşünürdüm. Korona sonrası bunların çok bir önemi kalmadı benim için. Her yer aynı gibi şu an. Her oda, her eşya aynı, işleosel sadece. Özel bir anlamı kalmadı. Çok iç içeyiz ondan sanırım, anlaml olması için biraz uzaklaşmam gerekiyor onlardan. (Bahar, kişisel iletişim, Mardin, 9 Mayıs 2020).

Durmak nasıl yeniden eyleme geçmek için şart ise, mesafe de anlamı kurmak ve deneyim için şarttır. Mesafeli aşinalık bireyin mekânla, nesnelerle kurduğu ilişkilenme için de geçerlidir. Evsel hareketlilik, nesnelerin işlevselliğini, işe yararlılığını baskın kılarken, bireyin evinde anlam kurma, rahatlama, kendileme süremini de azaltmış olabilir. Hanehalkının kendi sınırlarını ve alanlarını daha çok belirleme ihtiyacı da söz konusudur. Temizlik ve yemek yapma, paket silme gibi pratikler bazı bireylerin daha fazla zamanını alan, ortak alanlarda birlikte geçirilen zamanı da azaltan pratiklere dönüşmüştür.

Odamı çok kullanmiyordum eskiden. Yatmadan yatmaya. Salonda annem ve babamla akşamları vakit geçirdiğimiz bir günlük rutinimiz vardı. Şimdi neredeyse kayboldu o. Babam salonu komutasina aldı, annem kendini mutfağa adadı, ben de çoğunlukla kendi odamdayım. Bilgisayarımla yatı kalkıyorum. Sadece kahvaltı ve yemek saatlerinde üçümüz birlikte mutfaktayız. Resmen mekânları ayırdık, kimse başkasının alanına dâhil olmuyor. (Dilek, kişisel iletişim, Mardin, Mayıs 2020).

G. Ritzer (2011, s. 189), Büyüsü Bozulmuş Dünyayı Büyülemek kitabında, evin nasıl aşama aşama "tüketim mekanı" haline geldiğini açıklar. "Örneğin evde alışveriş olanağı sağlayan bilgisayar aynı zamanda orada çalışmamıza da olanak taniyor. (...) Ve ev, televizyon ve on-line kurslarıly gene önemli bir eğitim tüketme arac haline de geliyor. Üretim ve tüketim gene sık sık evde gerçekleşse de, aynı tür üretim ve tüketim değiller ve aynı şekilde ger- 
çekleşmiyorlar". Evde "çalışma alanı" birçok kişi için bu süreçte farklı bir anlam kazanır. Evde kısa süreli çalışmayla, mesai saatlerinin toptan içeriye taşınması arasında zamansal-mekânsal bir değişim, bir iç içe geçme hali var. Olumlu ya da olumsuz bir yanıttan uzak bakıldığında, bu süreçte evle kurulan "çalışma" ilişkisinin farklılaştığını söylemek mümkün. Bu ilişki, eve yeni çalışma nesnelerinin / mobilyaların girmesi, evde bir çalışma alanı oluşturulması, çalışma alanının değişmesi ya da odanın çeşitli şekillerde düzenlenmesi vb. etkiler oluşturmuştur.

Evde olduğum bir günde sabah kalkıp kahvaltı edip biraz mutfakta vakit geçirip ondan sonra genelde çalışma odasında ders çalışarak geçiriyorum. Bir şey izleyeceksek salona geçiyoruz ancak. Aktif olarak aslinda mutfak ve çalışma odası kullanilıyordu. Koronayla birlikte evde çalı̧maya başlayacağımı fark ettiğim günden itibaren, direk bütün çalışma eşyalarımı salona taşıdım. Bedo da işe gidemez, karşllkhl sürekli dip dibe olmayalım şeyiyle salona taşındım. Çünkü çalışma odasını ortak kullanıyoruz ve kütüphane gibi karşıllklı masalarımız var. (Dilan, kişisel iletişim, Ankara, 8 Mayıs 2020).

Mutfak, kamusallığıyla diğer odalardan başka bir 'yer' tarifler. Wendy Elizabeth Steele \& Ilan Vizel (2014, s. 77), ev ve madde (ateş, su, toprak ve hava) ilişkisini anlattıkları makalelerinde "ateş, evde kritik bir sosyal rol oynar. Daha eski zamanlarda ocak, evin içinde bir toplanma yeri olarak hizmet ediyordu. Günümüzde oturma odasında televizyonun yanıp sönen merkezi ışınları da benzer bir rol oynamaktadır" diye yazar. Ev içi kamusallık da teknolojiyle birlikte dönüşmüş görünmektedir. Yine de mutfak, bir araya gelinen, oturup sohbet edilen, dinlenilen, birlikte yemek yapılan ve yenilen bir yer olarak 'kamusal' önemini korumaktadır. Pandemiyle birlikte mutfağın kullanılma biçimleri ve anlamı da değişir. Yemek türlerinin ve porsiyonun değişmesi, yemek hazırlama ve mutfakta geçirilen zaman, yemek yenilen yerler, kullanilan malzemeler, yeni nesneler, depolama yeri ve temizleme süreci genel olarak vurgulanan değişimler arasındadır.

Yemek konusu çok değişti aslında. (...)íkimiz de işten çıttı̆̆mızda birbirimizi arardik, hani bir yemek yiyip eve geçelim gibi bir düzenimiz vardı. Kendimize hala inanamıyoruz, iki aydır dışarıdan yemek söylememize falan. (...) Evde sürekli malzeme var. Normalde çok şey olur ya, öğrenci evi kafası, yemek yapacaksin ama soğan yok, patates yok. Şu an evde her şey var o yüzden yemek yapmak daha kolay bir şey. Evde hiç yapmadığımız bir şeydi tatl yapmak. Onları yapıyoruz. (Burcu, kişisel iletişim, Ankara, 27 Mayıs 2020).

Pandemi öncesinde de nesnelerle kurduğumuz ilişkisellik dinamik bir özellik gösterse de, bir rutin dâhilindedir. Diğer yandan günlerin hep evde 
geçmesi, dışarıda geçirilen zamanın ve kamusal karşılaşmaların azalması, domestik nesnelerle karşılaşmaları ve ilişkiselliği arttırdığı için değişim öngörülemez, huzlı ve büyük olabilir. Alberto Eiguer (2018, s. 45) Evin Bilinçdışı'nda her bir odaya, her bir köşeye anlamını veren şeyin onun kullanılış şekli olduğunu yazar: "Bir konut alanı olsun, bir oda ya da birçok odadan oluşan bir alan olsun, her alan eylemle kurulur". (Müge, kişisel iletişim, İstanbul, Mayis 2020).

Biz normalde yemeklerimizi ya mutfakta yerdik ya salonda elimizde yerdik, sofraya oturmadan. Şimdi sofraya oturuyoruz akşamlar. Koltukta yemiyoruz, mutfakta yemiyoruz. Mutfak masasinın üstü şu an bir sürü şeyle dolu, kavanozlar, paketler. Mutfak masası her zamanki yemek yediğimiz, kahvaltı yaptı̆̆ımı işlevini yitirdi, onun yerine salonda her şeyi yapıyoruz. (Müge, kişisel iletişim, İstanbul, Mayıs 2020).

Başladı süreç, sürekli evdeyiz ve mutfak bizim çok küçük. Küçük olduğu için de işlemeyen taraflar var. Daha uzun sürelerle yemek yapmak için vakit geçirince mutfağın küçüklüğü daha çok gözümüze battı. Düzenlememiz gerektiğinin hep farkndaydık ama hem vakit bulamıyorduk hem de çok ihtiyaç hissetmiyorduk çok hızlı kullandığımı bir mekân olduğu için. (Tuba, kişisel iletişim, Mardin, 29 Mayıs 2020).

Mutfağa giren-çıkanların ve kullanımdaki farklılaşmanın dişında, yeni pratiklerin oluşturduğu eşya ihtiyacı ve mekânsal değişimler de dikkate değer. Ayakkabıların hijyenik gerekçelerle içeriye alınmaması, evin yeni çalışma alanı olması, evde spor yapılması vb. pratikler, ev içi "yeni" alanların oluşmasına ve çeşitli eşya/nesne ihtiyaçlarına sebep olur. Evin bu süreçte sosyal çevreyle vakit geçirilen bir yer olmaktan çıkması da mekânsal kullanımda farklı tür bir kendilemeye yol açmış olabilir.

Dışarıya ayakkabılık aldım. Ayakkabılarm içeriye alınmaması gerç̧ği oluştu. Dışarnda o görüntüyü sevmem. Süreci daha yumuşak geçirebilmek adma mutfağa masa örtüsü aldım. Yatağıma yatak örtüsü. Beni mutlu edecek şeyler... İlk günler hareketsizlikten dolayı pilates seti aldım ve kullaniyorum. (...) Bitki aldım, kaktüs. Ben aslinda hiç bakamam. (...) Hayatın hala devam ettiğine dair bana mesaj versin diye düşündüm. (Bahar, kişisel iletişim, Mardin, 9 Mayıs 2020).

Eyvandaki çalı̧ma tezgahını mutfağa götürdük. Orada ekstra çalışma alanı çıtı bize, iyi oldu. Eyvana raf aldık, eşyaları düzenlemek için. Bu raf da masif ahşap, sıcak bir malzeme. Bir anda eyvanda daha çok vakit geçirmeye başladık. (...) İ̧eride hasır bir koltuk vardı, onu da eyvana getirdik. Çalışma odası, mutfak, eyvan, yatak odası masalarmı kendi aralarında değģş̧irdik. Yatak odasın biraz düzenledik. (Tuba, kişisel iletişim, Mardin, 29 Mayıs 2020). 
Dışarının kamusallığı nasıl ki farklılaşıyorsa, içerisi de bu anlamda farklılaşır. Oturma odası mutfaktan, mutfak balkondan farklı bir eviçi kamusallık tarifler. Eve, hane üyesi olmayan, dışarıdan birilerinin girip-çıtığı bir ritimde, yaşayanların kullandığı nesneler bile 'diğerini 'gözeterek içerideki yerini alır. Bu durum bireyin toplumsallığın, evinin de "toplumsal bir üretim" (Lefebvre, 2019) olduğunu imler. Baudrillard (2011, s. 50) nesne-toplumsallık ilişkisini şu cümleyle açılar: "Konut sahibi nesnelerin odayla bütünleşmesini sağlarken, kendisi de toplumsal yapıyla bütünleşmiş olacaktır".

(...) Eve kimse girip çıkmıyor ya tamamen kendime göre yaşıyorum. Nasıl olsa kimse gelmiyor diyorsun, kapını arkasına aynayı koyuyorsun. Normalde çamaşırı da kapalı balkona seriyordum, o nedenle de firın çok kullanamıyordum. Şimdi kimse gelmeyecek madem diye misafir yatma odası çamaşır odasına dönüştü. Kapalı olan balkonu daha çok firn için kullanmaya başladım. (Dilan, kişisel iletişim, Ankara, 8 Mayıs 2020).

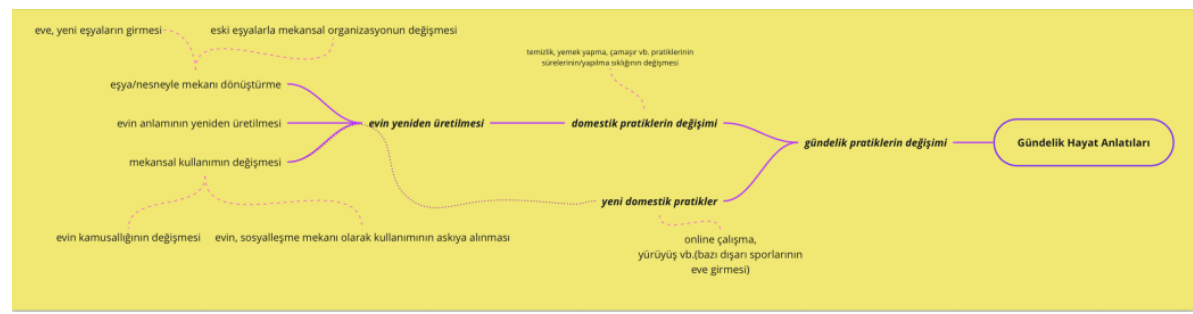

Şekil 2. Gündelik pratikler değişim diyagramı

\section{'Yeni Kamusallığın' Deneyimi}

Artık tüm sınırlar yer değiştirmektedir. Bu yer değiştirme kendini her tarafta açı̆̆a vurur: Elbette şehirde, ama aynı zamanda şehir mekânını tanımlayan bütün o teknolojilerde de: demiryolu, gazeteler, fotoğraf, elektrik, ilanlar, betonarme, cam, telefon, film, radyo... savaş. Bunların hepsi dışarısı ve içerisi, özel ile kamusal, gece ile gündüz, derinlik ve yüzey, burası ile orası, sokak ile içmekan, vb. arasındaki eski sınırları yerinden eden birer düzenek olarak görülebilir (Colomina, 2020, s. 12).

Beatriz Colomina (2020, s. 12)'ya göre geleneksel anlamda dışarısının karşısında konumlandırılmış bir içerisi yoktur artık. Colomina'nın yukarıda sözünü ettiği, şehir mekanını etkileyen durumlara günümüz pandemisini de eklemek gerekir. Pandemi koşulları, kentsel rutinimizi ve alışkanlıklarımızı hızla değiştirirken, ev ve kent mekânı ilişkisinin başkalaşmasına, bir anlamda sınırın belirginleşmesine neden oldu. İçerisi ve dışarısı arasında oluşan bu sınır, kentlere ve toplumsal dinamiklere göre farklılaşıyor; kentsel donatılar ve 
yeşilin kent peyzajinda yerini bulduğu, eşitlikçi kentler için daha geçirgen, ince bir sınırken, diğer kentler için belirgin ve net bir çizgi oluyor.

Sadece ihtiyaçların karşılandığı, işlevsel bir dışarısı, gerçek mekânla kurulan ilişkiselliğin azalması anlamına gelmekte, çeşitli kamusal tartışmaları da beraberinde getirmektedir. Kamusal alanların bu süreçten nasıl etkileneceği, mekânsal niteliklerin ne ölçüde değişeceği, yeşil alan ve ulaşım başta olmak üzere kimi örüntülere ilişkin toplumsal kazanım olasılıkları bu tartışmaların başında gelmektedir. "İnsanlar mekânı yalnızca tecrübe etmez, aynı zamanda onun aracilığıyla düşünür ve hayal kurarlar" (Stavrides, 2018, s. 11). Kentsel mekâna dair hayallerin 'evden' kurulduğu bir dönemde, bireyin kentsel mekânla ilişkilenme biçimlerine ve ne tür taktikler oluşturduğuna bakmak, kamusal mekânların / performansların dönüştürücü etkisini anlamada çeşitli açılımlar sağlayabilir.

Yürüme eylemi, bireyin kenti deneyimlemesi bağlamında oldukça önemlidir. De Certeau (2009, s. 52), yürüyüşün, anlamlı kabul edilen günlük operasyonlardan biri olarak özellikle betimlenmesi gerekliliğini ifade eder. Yürüyüş pratiği, Lefebvre'nin yabancılaşmamış aktif tutum dediği türden bir pratiktir. ${ }^{10}$ Zaman içinde daha çok tüketime dayalı sektörel alanları oluşsa da (yürüyüş bandı, spor salonları vb.) yürüyüş pratiği, çeşitli karşılaşmalar, olasılıklar ve ilişkiler barındıran yapısıyla bireye, deneyim ürettirir. De Certeau (2009)'ya göre, yürüyüşçü bir var edendir: "Yürüyen kişi uzamın her göstergesini farklı bir şeye dönüştürür; olasılık ve yasakların yerlerini değiştirir ve bunlardan yola çıkarak başkalarını icat eder. Yürüyen kişi seçen, seçim yapan kişidir"(s. 194). Yürümenin yarattığı devinim bedensel olduğu kadar zihinsel bir ihtiyaçtır.

Spor yapmayı seven bir insan değilim. Her gün 1500 adım evin bir ucundan diğer ucuna müzik eşliğinde gidip geliyorum. Bu çok bir şey değil, normalde dışarıda olduğumda attığım adımlardan az belki. Ama evin içine taşımak durumundayım artık. (Dilek, kişisel iletişim, Mardin, 15 Mayıs 2020).

Parkta yürürdüm kulaklklarımı takıp ya da spor yapmak için (pilates) salona giderdim. Şimdi çalışma odası ( $L$ alan) ve salon arasındaki bölgeyi spor alanı olarak belirledik. Çünkü halı yok. Bir YouTube videosu açıp arkadaşımla birlikte yapıyoruz.

\footnotetext{
${ }^{10}$ Lefebvre, boş vaktin aktif ya da pasif eylemlerle nasıl doldurulduğunu örnekler üzerinden açıklar. Örneğin, ekran karşısında geçirilen zamanı pasif tutum olarak örnekler. "Başlangıçta, boş vakit, gündelik hayatın diğer veçhelerinden pek ayrılamayan küresel ve farklılaşmamış bir faaliyete yer verir (pazar günü ailecek gezinti, yürüyüş)", 2012, ss. 37-38.
} 
Evde ilk kez denediğim bir şey, spor. Ara bir zamanım kalmadı gibi. Her dakikaya bir şey sığdırıyorum şimdi. (Burcu, kişisel iletişim, Ankara, 27 Mayıs 2020).

Pandemi sürecinde "yürümenin zorluğu", kentin sermaye eylemleriyle (konut ağları, tüketim mekânları vb.) ne denli doldurulmuş ve sıkışmış olduğu gerçeğiyle bizi çarpıcı şekilde yüzleştirir. Yürüyüşçü için deneyim üretme hali gittikçe zorlaşmakta, yürüyüşün retoriği kaybolmaktadır. Kentin tıkış tıkışlığıyla gündelik hayat üzerindeki denetimin birbirlerine muhtaç ilişkiselliği, öznenin kentle ve kamusal pratiklerle kurduğu spontan/sürprizli ilişkilerin önemini bir kez daha ortaya koyar. David Harvey (2010, s. 241) bu durumu şu cümleyle ifade eder: “Örneğin, yoksullaşmış kitlelerin iç kentlerde kıstırılmış olarak yaşaması, kent coğrafyacılarının uzun zamandır dikkatini çekmekte olan bir konudur". Ev, içeri ve dışarı ilişkiselliğinin kurulabilmesine olanak sağladığı ölçüde bir anlamda da ev olabilmektedir. Bir karşıtlığın tarafı olarak değil; birinden diğerine kendiliğinden bir geçişin kurulabilmesinin, bireysel ve toplumsal devinimin, ötekiyle karşılaşmanın ve istenildiği zaman mesafe koyabilmenin yeri ve koşulu olarak.

Dışar çıkma isteğgi oldu bende. Deprem oldu. 14. Katta olmanın tedirginliği oldu. Sıkışmış hissettim. Açık havada dışarıda olmak ve keyfimce işime gidip gelmek. Hareket ediyor olmann büyük bir özgürlük olduğunu düşünüyorum. Ev, dar bir mekân sonuçta. Evin somut anlamda darlğını hissettim. Zihnim onu genişletmedi ve bir anda dışarıda olmayı çok istedim. Dışarısı çok da güvensiz gelmiyor hala. (Sıdıka, kişisel iletişim, Şanlıurfa, 29 Mayıs 2020).

Stavrides (2018), Kentsel Heterotopya kitabında "(...) yalnızca boş zamanı değil, icra edilen pratiklerin sosyal bakımdan anlamlı zamanını da kamusal alanla bütünleştirmemiz gerekir" diye yazar. Kamusal alanın niteliklerini anlamak için de ritim kavramını önerir (Stavrides, 2018, s. 29). Ritim kavramı gündelik hayatın içindeki tekrarları ve farkı aynı anda içermesi açısından önemlidir. "Ritimde zamanın doğrusal ve mekanik tekrarlanışından öte bedensel ve döngüsel bir olageliş söz konusudur" (Lefebvre, 2018, s. 32). Hissedilir olanı yani bireyin "şimdi" deki deneyimini imler. Pandemi, mekanik zamanın manipüle edilmesi, onun yerine bireyin evdeki ritminin ve tüm belirsizliği içinde "yaşanılan günün" öne çıkması açısından da ele alınabilir. "Yaşanmış olanın bilgisi, yaşanmış olanı bilmeden değiştirir, onu başkalaştırır" (Lefebvre, 2018, s. 44). Gündelik pratiklerimiz üzerine düşünmek, kentsel üretimin de buradan hareketle kurulduğunu, özellikle kriz ortamlarında / k1rılma anlarında, öneminin daha da arttığını görmek durumundayız. Özne, 
evinin "mikro ölçeğinde" bununla yüz yüze gelirken ve "olanı" dönüştürürken, toplumsal/kentsel üretim süreçlerinde de her durumda dönüşümün aktörlerinden olmalıdır. Kentin "tüketici tatmini amaçlı bir fırsatlar yığını olarak gösterme" (Stavrides, 2018, s. 32) eğiliminin olduğu her durumda farklı toplumsal ilişkilerin, anlamlı serbest zamanın, çeşitli ritimlerin ve performansların yeri haline gelecek kamusallıkların yaratılmasının yollarının aranması önemlidir. Pandemi öncesi kentinde olduğu gibi pandemi sonrası kentinde de ötekinin beklentilerine ve deneyimine yer açan kamusal alanların oluşturulmasına ihtiyaç vardır.

Onu kullananlarin pratikleriyle ve devinimleriyle yaratılan; bireyin bulunduğu, ötekiyle karşılaştı̆g 1 ve müzakere ettiği kamusal alanların "nasıl oluşturulacağı" sorusu yeni bir soru olmamakla birlikte, ekonomik ve sosyopolitik nedenlerle kolay görünmemektedir. "Günümüz kentinde ise çoğunlukla "kamusal hayat" alanları olarak tanımlanan şey, çekişen pratiklerin çarpışan ritimleri değil, gözetim altındaki rutinlerin düzenlenmiş ritimleridir" (Stavrides, s. 33). Dinamik kamusallıkların oluşması pandemi öncesinde olduğu gibi pandemi sonrası da, bireylerin etkin bir şekilde yer aldıkları sivil inisiyatifler tarafından gerçekleştirilecek çabayla ancak mümkün görünmektedir. "İş ve toplumsal katılım alanlarında uzun vadeli yatırımları ödüllendirmeyen toplumlarda insanlar yaptıklarına anlam katacak bir gelecek perspektifi geliştiremezler" (Wittmann, 2019, s. 28).

Tüm bunların içinde ve ötesinde, Stavrides (2018)'in de vurguladığı gibi, baskılanmış ve eksiltilmiş olsalar da yerlerin, farklılıkların karşılaşma, çatışma ve müzakere alanı olarak deneyimlenmesi ve üretilmesi günümüz kentinde dinamik bir süreç olarak sürmektedir. Parkların aktif olarak kullanılması ve çoğaltılmasına yönelik girişimler, gidanın öneminin artması ve kent içi üretim ağlarının oluşturulması, kent içi boş ve 'atıl 'durumdaki alanların ağaçlandırılması ve kullanıma açılması, "ortak dış alanların düzenlenmesi, konut ile kamusal alan arasındaki ara mekânın"11 (Lamontre-Berk, 2020, s. 22) ve terasların dönüştürülmesi ve kolektif kullanımı bunların başında gelmektedir.

"Gündelik zamanın ritimli örgütlenmesi bir anlamda en kişisel, en içsel olandır" (Lefebvre, 2018, s. 102). Edinilmiş ritimler yeni bir durumla, Lefebvre (2018)'nin ifadesiyle “öğe"yle, karşılaştığında öznenin içsel ritmi,

11 "Pandemide Kentsel Sistem: Yaşama, Çalışma ve Sosyalleşme Mekânlarında Yeni Standartlara Doğru" başlığıyla yayınlanan dergideki bazı çalışmalar da mahallenin, mekânın, kentsel sistemin; eşitlikçi, dayanışma örüntülerini destekleyen, erişilebilir, kolektif üretimlere olanak veren ve bu dinamiklerle üretilen yapısının oluşturulmasına yönelik tartışmalara yer vermektedir. 
gündelikliği başkalaştırır. Öznenin kendinden gündelikliği, mekânda ve zamanda karşılık bulur; verili/zorunlu sanılan durumlar değişir, dönüşür. Evde hem kendi ritmimizle hem etrafımızı oluşturan nesnelerin ritmiyle yüz yüze gelmenin çeşitli gündelik, bireysel ve kamusal karşılıklarının farkında olmak önemlidir. Öznelerin evdeki beklentileri, aynı zamanda toplumsal beklentiler demektir. Gündelik yaşamı bireysel anlamda yaratıcı ve doyurucu kılacak kimi eylemlerin nasıl mekânsal/toplumsal karşılıklar yaratacağını ancak ilerleyen zamanlarda görebileceğiz.

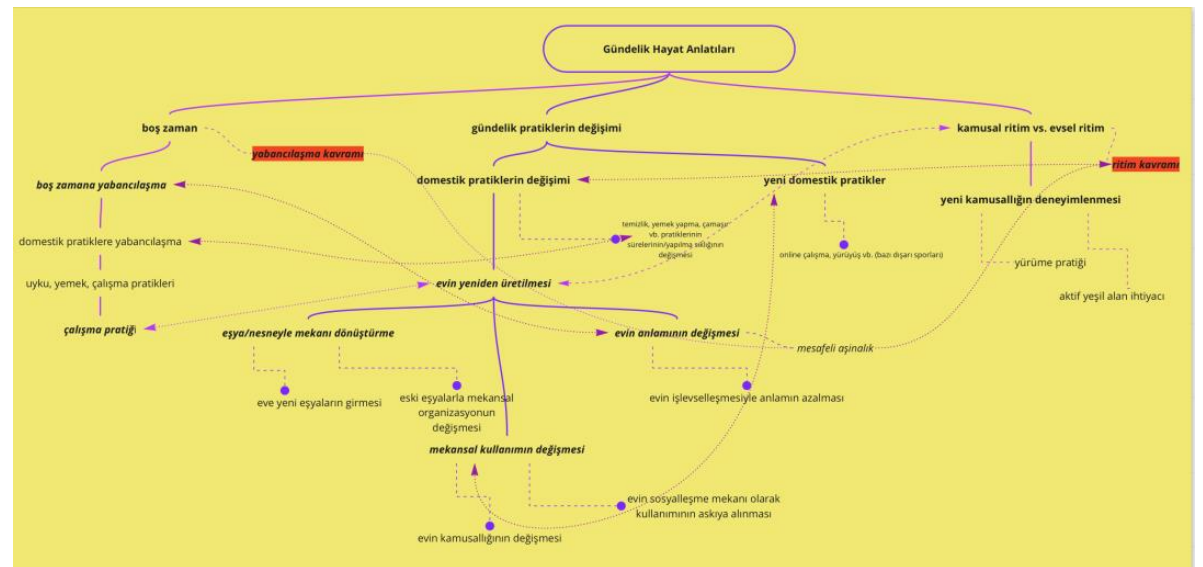

Şekil 3. Kavramsal açılım diyagramı

\section{Tartışma ve Sonuç}

Pandemi sürecinde, kentin sıkışmışlığı, ağaçsızlığı ve kamusal alan yetersizliğiyle daha çok yüzleştik. Evin fizikselliği, yapılan görüşmelerde ‘özel olarak' vurgulanan bir özellik olmamanın ötesinde, beliren kimi ihtiyaçlar eve alınan çeşitli mobilyalar ve nesnelerle çözümlenmiş; eylemler, evin farklı alanlarında yer değiştirmek suretiyle yeniden oluşturulmuştur. Çalışma pratiğinin eve taşınması, birçok özne açısından, evdeki mekânsallığı ve eylemleri dönüştürücü bir dinamik olmuştur. Verimlilik ve üretkenlik meselesinin, öncesinde evde dinlenme / rahatlama imkânı bulan özneler için, evdeki gündelikliği tüketici bir baskı aracı oluşturduğuna dair vurgu, ayrıca önemlidir. $\mathrm{Bu}$ durum, öznenin alışkanlıklarına, kimi domestik pratiklerine ve boş zamanına da yabancılaşmasına neden olmuştur. Çalışma pratiğinin, ilerleyen yıllarda evi, başlı başına dönüştürecek öncelikli pratiklerden biri olacağı düşünülmektedir. Eve bu süreçte giren diğer pratiklerin, gündelik pratiklerimizden eksilen kimi alışkanlıklarımızın ya da dönüşmek durumunda kalan bireysel / 
toplumsal kimi pratiklerin, evi ve kentsel mekanı ne ölçüde dönüştüreceği çok boyutlu bir mesele olarak, belirsizliğini korumaktadır.

Aşina olunduğu için üzerine düşünülmeyen kimi eylemlerin mekânsal etkileri; gündelik hayatın potansiyellerinin ve imkânlarının verimlilik çerçevesinden bağımsız olarak, bireyin öznel / yaratıcı eylemlerinden üretilmesi gerekliliği, her dönemde olduğu gibi bu süreçte de önemini korumaktadır. Bundan sonrası için farklı kolektif / toplumsal ihtiyaçları ortaya koymak ve gündelik hayatın eksiltilmesi karşısında yeni "taktikler" oluşturmak, mekansal imkanların birey / toplumsal lehine genişlemesine olanak sağlayabilir. Deneyimin, gündelik pratiklerle ilişkisinin farkında olmak bireyin, 'yeni kamusallığa' etki etmesi açısından önemlidir.

Zamansal kırılmalar ve durumlar önemli olsa da, yine her birey "olanı" kendince ve pandeminin yarattığı etki dolayımıla yorumladı, yaşadı. Bu etkinin, ev mekanına yansıması; kimi domestik pratiklerin eski önemini yitirmesi, bazı gündelik pratiklerin evde, eskisinden daha çok yer kaplaması ya da kimi 'dışarı' eylemlerinin içeriye girmesi şeklinde çeşitlendi, çeşitlenmeye devam ediyor. Bu çalışma pratiklerdeki 'pandemi etkisinin', mekanı çok boyutlu dönüştürme biçimlerini ortaya koymayı amaçlamıştır. Ev ve kamusal alanın, sadece fizikselliğiyle yorumlanamayan ve kurulamayan; bireysel / toplumsal ilişkilerin ve tarihsel / zamansal dinamiklerin sürekli değişimi içinde üretilme hallerinin ön plana çıtığ yandan kentsel örüntülerin ve kamusal alanların, pandemi koşullarında dahi olsa bireye alan açan, dışarıda olabilmesine olanak sağlayan yapılanmasının ve fiziksel özelliklerinin de her bakımdan kaçınılmaz önemiyle yüzleşmek gerekir. Mekanla bu türden bir yüzleşme, yaratıcı kamusal eylemler, iş birliği ve müzakere süreçlerinin oluşturulması açısından ayrıca önemlidir. 


\title{
Extended Abstract
}

\section{Home In Times Of The Pandemic: Daily Practices and The Experiences Of New Publicity}

\author{
Zemzem Taşgüzen Pülat \\ ORCID: 0000-0001-7766-4487
}

Home means sociality, it is the place where we establish our individual and social existence. Although it is difficult to draw the line between the individual and the social, the home marks and constantly reconstructs individual and social intersections. When the pandemic began, we started to think about the house, more intensely than before. We heard many slogans about home (stay at home/save lives, there is life at home, life fits in the home) and we were bombarded with images regarding what home means. We came across lots of messages that the home can be the place for many activities that were typically performed outside. Indeed, in pandemic times, the home has become the "only place" where we can be "safe" against the "uncanny" outside.

In order to create a dialogue and understand the diversity of experience, an individual in-depth interview method was used in the study. Women who lived at home with households and were able to work at the home-office, were interviewed by Zoom video-conferencing program in May 2020. Some topics came to the fore and were repeated in different ways by the interviewees, predominantly: The transformation of practices and space, the search for ways to benefit from space, alienation from free time and the incompatibility of social expectations and rhythms with individual's daily/domestic rhythm, inadequacy of public space.

The rhythm of the outside and social expectations have also changed the free time of the individual and the ways of transforming it. Three of the interviewees indicated this form of alienation as "expectation of productivity", "not 
being able to balance", "overpraising digitalization", "becoming untimely". Sleeping, eating and working practices have been deemed as most alienated practices. The blurring of time and space boundaries between practices determines the criterion of alienation. The work space can be the living room, bedroom, study room or kitchen of the house. Domestic situations such as the presence of the household in the working space and the formation or failure of the individual space affect the alienation criteria.

Another important subject is about the ways of transforming the 'physicality' of the homes with daily practices of inhabitants. While the regulations of lockdown structured the actions of the society in pandemic times, it also caused them to be limited of domestic practices. This limitation has allowed the individual to redefine the meaning and physical boundaries of the house, and to transform it in various ways. Many attitudes, domestic and daily practices that had become our routine and before have changed. The duration, place and ways of doing of daily practices have changed including grocery shopping, cleaning, eating-drinking, working, sports, walking, sleeping, etc. The places that were used the most before turned into the places that were used the least and vice versa, also the objects that were not used much before have turned into objects that were used frequently. For some individuals, objects/items/furniture have ceased to be as important as they used to be. At the same time rather than objects/things, practices that are beneficial for family members have increased in daily practice; and likewise new practices have emerged. While domestic mobility dominates the functionality and usefulness of objects, it may also have reduced the individual's time to make sense and relax at home. Practices such as cleaning, cooking and practices directly related to pandemic like wiping packages took more time for some family members and reduced the time spent together in common areas. Even before the pandemic, our relation with objects shows a dynamic feature, but they are utilized in a routines. Some pandemic practices such as leaving shoes at the outside, working and doing sports at home, etc. have led to the need of "new" spaces for various items/objects. The fact that the house has ceased to be a place of socialization has also led to a different kind of selfing of home.

Furthermore, the boundary between home and urban space became clear with the pandemic. This border differs according to cities and social dynamics; while it is more permeable and thin for egalitarian cities where urban equipment and green find their place in the urban landscape, but it is a clear line for other cities. The "difficulty of walking" during the pandemic has brought us to a striking confrontation with the fact that the city is filled and 
stuck with capital actions (housing networks, consumption spaces, etc.). The relationality of the cramming city and the control over daily life once again revealed the importance of the real needs of the individuals. The house can be a house in a sense to the extent that it allows the relationship between inside and outside; a spontaneous transition from one to the other and as the place of individual and social movement, of encountering the other and being able to distance when desired. We have to see that urban production is built from our daily practices, and its importance increases even more, especially in crisis environments and moments. While the subject comes face to face with it at the "micro scale" of the home, he/she must also be one of the actors of the transformation in the social / urban production processes. As in the prepandemic city, there is a need to create public spaces with the expectations and experience of "the other" in the post-pandemic city. The production of dynamic public spaces seems possible only after the pandemic, as well as before the pandemic, with the efforts to be made by the societies and innovative civil initiatives in which individuals are equipped and actively involved.

\section{Kaynakça/References}

Baudrillard, J. (2011). Nesneler sistemi. Çev. Oguz Adanır, Aslı Karamollaoglu. İstanbul: Bogaziçi Üniversitesi Yayınevi.

Colomina, B. (2020). Mahremiyet ve kamusallık. Çev. Aziz Ufuk Kılıç. İstanbul: Metis Yayıncilik.

De Certeau, M.(2009). Gündelik hayatın keşfi-I, Çev. Lale Arslan Özcan. Ankara: Dost Kitabevi Yayınları.

Eiguer, A. (2018). Evin bilinçdısı. Çev. Perge Akgün. İstanbul: Baglam Yayıncılık. Gardiner, M. (2016). Gündelik hayat eleştirileri. Ankara: Heretik Yayınları.

Gürbilek, N (2020). İkinci hayat: Kaçmak, kovulmak, dönmek üzerine denemeler. İstanbul: Metis Yayıncillk.

Gürbilek, N. (2010). Ev ödevi. İstanbul: Metis Yayıncılık.

Han, B. C. (2019). Zamanın kokusu, Çev. Şeyda Öztürk. İstanbul: Metis Yayıncıllk.

Harvey, D. (2010). Postmodernliğin durumu. Çev. Sungur Savran. İstanbul: Metis Yayincilik.

Lefebvre, H. (2018). Ritimanalizm mekân zaman ve gündelik hayat. Çev. Ayşe Lucie Batur. İstanbul, Sel Yayıncilık.

Lefebvre, H. (2012). Gündelik hayatın eleştirisi I, Çev. Işık Ergüden. İstanbul: Sel Yayınları.

Lefebvre, H. (2019). Mekanın üretimi. Çev. Işık Ergüden. İstanbul: Sel Yayınları. Marx, K. (2018). 1844 El yazmaları. Çev. Murat Belge. İstanbul: İletişim Yayınları. Ritzer, G. (2011). Büyüsü Bozulmuş Dünyayı Büyülemek. İstanbul: Ayrıntı Yayınları. 
Suner, A. (2015). Hayalet ev yeni Türk sinemasinda aidiyet, kimlik ve bellek. İstanbul: Metis Yayıncilik.

Stavrides, S. (2018). Kentsel heterotopya. Çev. Ali Karatay. İstanbul: Sel Yayıncılık.

Wittmann, M. (2019). Hissedilen zaman. Çev. Özde Duygu Gürkan. İstanbul: Metis Yayıncilik.

Lamontra-Berk, Ö. (2020). Karantina ve şehir üzerine notlar, Spektrum, 1, 21-22.

Steele, W. E., Vizel, I. (2014). Housing and the Material imagination - earth, fire, air and water, housing. Theory and Society, 31(1), 76-90, 77. doi: https://www.tandfonline.com/doi/abs/10.1080/14036096.2013.801362.

Düzen, E., Gezici Yalçın, M. (2020, 25 Haziran). 23 Temmuz 2020 tarihinde https://www.birikimdergisi.com/guncel/10167/yeni-deneyimlerin-mahaliolarak-salgin-gunlerinde-ev adresinden erişildi.

Yırtıcı, H. (2020, 21 Mayıs). Toplama Ev İşgal Altında. Gazete Duvar. 29 Haziran 2020 tarihinde https://www.gazeteduvar.com.tr/yazarlar/2020/05/21/toplama-ev-ev-isgal-altinda/ adresinden erişildi. 